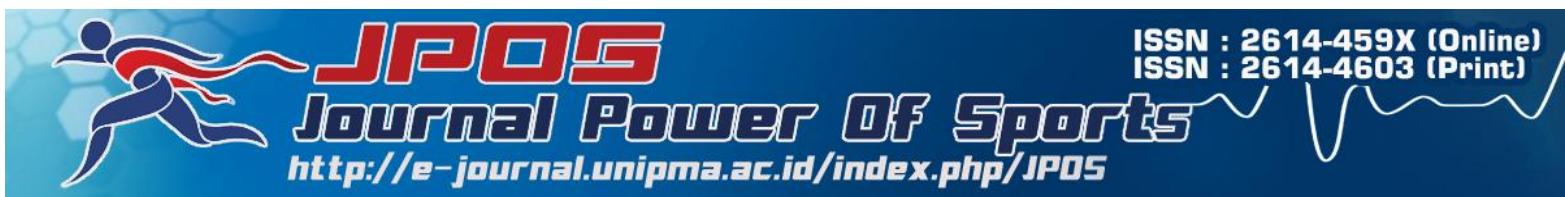

\title{
Analisis kondisi fisik tim bulutangkis Universitas PGRI Semarang
}

\section{Utvi Hinda Zhannisa ${ }^{1}$, Ibnu Fatkhu Royana ${ }^{2}$, Bertika Kusuma Prastiwi ${ }^{3}$, Dani Slamet Pratama ${ }^{4}$}

Program Studi Ilmu Keolahragaan, Universitas PGRI Semarang, Indonesia Email: utvihindaxhannisa@upgris.ac.id ${ }^{1}$, ibnufatkhuroyana@upgris.ac.id ${ }^{2}$, bertikakusumaprastiwi@upgris.ac.id ${ }^{3}$, danislametpratama@gmail.com ${ }^{4}$

Received: 30 Mei 2018. Accepted: 8 Agustus 2018. Published: 31 Agustus 2018

\begin{abstract}
Abstrak
Penelitian ini bertujuan untuk melihat tingkat kondisi fisik tim bulutangkis UPGRIS yang meliputi daya tahan, daya ledak otot tungkai, kekuatan otot tungkai, kecepatan, kelincahan dan Fleksibility. Metode penelitian ini merupakan penelitian deskriptif. Penelitian dilaksanakan di lapangan bulutangkis Mira Sakti Semarang pada bulan November 2017 Januari 2018. Penelitian mengambil sampel sebanyak 24 atlet putra pemain bulutangkis UPGRIS. Hasil penelitian menggambarkan bahwa rata-rata kecepatan relatif sedang dengan rentangan nilai 8,8" - 9,99". Rata-rata kelincahan relatif baik dengan rentangan nilai 15,20 16,19. Rata-rata kekuatan otot lengan relatif sedang dengan rentang nilai 36,50-46,00. Ratarata daya ledak otot tungkai relatif baik dengan rentang nilai 254-279. Rata-rata daya tahan (VO2Max) relatif sedang dengan rentang nilai 38,40 - 45,10. Rata-rata Flexibility relatif sangat baik $>28$.
\end{abstract}

Kata Kunci: Kondisi fisik; bulutangkis.

The analysis of the physical condition of the badminton team Universitas PGRI Semarang

\section{Abstract}

This research aims to know the level of physical condition of badminton teams that includes endurance, muscle limb power, leg muscle strength, speed, agility and flexibility. This research method is descriptive research. The research was conducted at badminton field Mira Sakti Semarang in November 2017 - January 2018. The research took sample as many as 24 athletes of badminton players. The results of this study illustrate that the average relative speed with a range of values of 8.8 "- 9.99". Average agility is relatively good with a range of values of 15.20 - 16.19. Average arm muscle strength is relatively moderate with a range of values 36.50 - 46.00. The average leg muscle explosive power is relatively good with a range of values 254-279. Average durability (VO2Max) is relatively moderate with a range of values 38.40 - 45.10. Average Flexibility is very good $>28$.

Key Words: Physical conditions; badminton. 
How To Cite : Zhannisa, U. H., Royana, I. K., Prastiwi, B. K., \& Pratama, D. S. (2018). to APA Style Analisis kondisi fisik tim bulutangkis Universitas PGRI Semarang. JPOS (Journal Power Of Sports), 1 (2), 30-41.

\section{PENDAHULUAN}

Dalam upaya meningkatkan prestasi dalam olahraga, faktor kondisi fisik menjadi sangat penting. Kondisi fisik yang baik diperlukan oleh atlet dalam setiap cabang olahraga guna menunjang pelaksanaan teknik dan taktik saat berlatih atau bertanding. Kondisi fisik yang baik merupakan salah satu cara untuk pencapaian prestasi. Sajoto (1988) menyatakan bahwa kondisi fisik adalah satu prasyarat yang sangat diperlukan dalam usaha peningkatan prestasi seorang atlet, bahkan dapat dikatakan sebagai keperluan dasar yang tidak dapat ditunda atau ditawar lagi. Harsono menyatakan bahwa kondisi fisik atlet memegang peranan yang sangat penting dalam program latihannya. Program latihan kondisi fisik haruslah direncanakan secara baik dan sistematis dan ditujukan untuk meningkatkan kesegaran jasmani dan kemampuan fungsional dari sistem tubuh sehingga dengan demikian memungkinkan atlet untuk mencapai prestasi yang lebih baik.

Dijelaskan tentang kondisi fisik dan komponen-komponen kondisi fisik oleh Sajoto (1988) sebagai satu kesatuan utuh dari komponen yang tidak dapat dipisahkan, baik peningkatannya maupun pemeliharannya. Artinya bahwa setiap usaha peningkatan kondisi fisik, maka harus mengembangkan semua komponen tersebut. Komponen kondisi fisik meliputi, kekuatan (strength), daya tahan (endurance), daya ledak (muscular power), kecepatan (speed), daya lentur (flexibility), koordinasi (coordination), keseimbangan (balance), ketepatan (accuracy), reaksi (reaction). Dalam permainan bulutangkis, komponen kondisi fisik yang dominan adalah daya tahan (endurance), daya ledak otot tungkai (explosive power), kecepatan (speed) dan kelincahan (agility).
Seorang atlet bulutangkis membutuhkan kelincahan (agility) yang baik. Kelincahan merupakan hal yang pokok untuk seorang atlet bulutangkis, misalnya untuk dapat menjangkau shuttlecock diseluruh lapangan bulutangkis seorang pemain harus mempunyai kelincahan yang baik sehingga dapat menguasai lapangan dengan maksimal.

Selanjutnya komponen kondisi fisik untuk seorang atlet bulutangkis adalah kecepatan (speed). Kecepatan memiliki peran yang tidak kalah pentingnya dengan komponen kondisi fisik lainnya. Komponen selanjutnya adalah daya ledak otot tungkai (explosive power) yang sangat baik. Daya ledak otot tungkai merupakan kemampuan otot tungkai dalam melakukan aktivitas secara cepat dan kuat sehingga menghasilkan tenaga maksimal.

Komponen selanjutnya adalah daya tahan (endurance) yang merupakan kemampuan dan kesanggupan tubuh untuk melakukan aktivitas olahraga dalam waktu yang lama tanpa mengalami kelelahan yang berarti. Para pemain dituntut untuk memiliki tingkat daya tahan yang baik. Tuntutan itu didasarkan kepada tugas dan tanggung jawab sebagai atlet bulutangkis yang harus terus bergerak.

Dari uraian di atas dapat kita lihat, olahraga bulutangkis merupakan sebuah permainan yang sangat membutuhkan kondisi fisik yang baik. Kondisi fisik yang baik dibutuhkan dalam memadukan keterampilan teknik, taktik dan mental pemain di dalam lapangan permainan. Dengan melihat kondisi fisik yang dominan dalam permainan olahraga bulutangkis, maka dibutuhkan latihan secara khusus untuk meningkatkan kondisi fisik bagi para pemain sehingga dapat meningkatkan performa atlet dan atlet dapat berprestasi lebih baik.

Untuk dapat bermain bulutangkis dengan sebaik mungkin dengan 
menggunakan teknik, taktik, dan unsurunsur fisik yang dimiliki.Untuk mencapai prestasi tinggi dalam permainan bulutangkis harus didukung dengan kondisi yang prima. Cabang olahraga bulutangkis bersifat compotitive sport yang membutuhkan kesiapan fisik, teknik, taktik, dan mental. Seorang atlet juga harus memiliki teknik dasar bermain bulutangkis yang benar. Berdasarkan uraian yang telah peneliti kemukakan, maka peneliti tertarik mengadakan penelitian terhadap permasalahan yang dikemukakan, pada pemain bulutangkis UPGRIS.

\section{Permainan Bulutangkis}

Bulutangkis atau badminton adalah olahraga raket yang dimainkan dua orang (untuk tunggal) dan dua pasang (untuk ganda) yang mengambil posisi berlawanan di bidang lapangan yang dibagi menjadi dua yang dibatasi oleh net (jaring). Bulutangkis merupakan sebuah permainan yang menggunakan raket untuk memukul shuttlecock yang dipukul bolak-balik melewati atas net dan arah shuttlecock berada dalam garis lapangan bulutangkis.

Menurut Subarjah (2000: 13) bahwa permainan bulutangkis merupakan permainan yang dilakukan dengan cara salah satu peserta didik melawan salahsatu peserta didik atau dua peserta didik melawan dua peserta didik. Menjadi pemain bulutangkis yang elite atau berpestasi, peserta didik harus menguasai bermacam-macam dasar bermain bulutagkis secara benar. Dengan modal bermain tekun, disiplin, terarah di bawah bimbingan pelatih yang berkualitas baik, peserta didik dapat menguasai berbagai teknik dasar bermain bulutangkis secara benar (Akhsan, 2012: 52).

Yousif \& Yeh (2011: 61) menyatakan bahwa "nowdays, badminton can consider as one of the famous sport in the world." Tidakdapat dipungkiri, bahwa saat ini cabang olahraga bulutangkis merupakan salah satu jenis cabang olahraga permainan yang cukup terkenal di Dunia. Konsep dasar dari cabang olahraga permainan bulutangkis adalah memertahankan shuttlecock supaya tidak jatuh di bidang lapangan sendiri dan berusaha menjatuhkan shuttlecock ke bidang lapangan lawan. Dalam cabang olahraga permainan bulutangkis, peralatan yang digunakan untuk memukul shuttlecock adalah raket, setiap pemain hanya diperkenankan melakukan pukulan shuttlecock sebanyak satu kali dan boleh memukul shuttlecock lagi jika sudah dipukul oleh lawan.

Berdasarkan beberapa pendapat di atas, dapat disimpulkan bahwa bulutangkis adalah salah satu cabang olahraga yang cukup terkenal di dunia, yang dimainkan dengan shuttlecock yang dipukul dengan raket dan harus melewati net. Bulutangkis dapat dimainkan dengan cara satu peserta didik melawan satu peserta didik atau dua peserta didik melawan dua peserta didik. Dalam bermain bulutangkis, terdapat berbagai keterampilan dasar yang harus dikuasai agar permainan yang berlangsung dapat berjalan dengan baik, keterampilan tersebut antara lain adalah seperti sikap berdiri, teknik memegang raket, teknik memukul shuttlecock, dan teknik langkah kaki.

\section{Komponen Kondisi Fisik}

Kondisi fisik adalah salah satu kesatuan utuh dari komponenkomponen yang tidak dapat dipisahkan begitu saja, baik peningkatan maupun pemeliharaannya. Artinya, bahwa didalam usaha peningkatan kondisi fisikmaka seluruh komponen tersebut harus dikembangkan. Menurut Sajoto (1988: 57), bahwa komponen kondisifisik meliputi:

1. Kekuatan (strength), adalah komponen kondisi fisik seseorang tentang kemampuanya dalam mempergunakan otot untuk menerima beban sewaktu bekerja.

2. Daya tahan ada 2 dua macam, yaitu:
a) Daya tahan umum yaitu kemampuan seseorang dalam mempergunakan sistem jantung, 
paru-paru dan peredaran darahnya secara efektif dan efisien.

b) Daya tahan otot adalah kemampuan seseorang dalam mempergunakan ototnya untuk berkontraksi secara terus menerus dalam waktu yang relatif lama dengan beban tertentu.

3. Kekuatan otot adalah kemampuan seseorang dalam mempergunakan kekuatan maksimum yang digunakan dalam waktu yang sesingkat singkatnya.

4. Kecepatan adalah kemampuan seseorang untuk mngerjakan gerakan keseimbangan dalam bentuk yang sama dalam waktu yang sesingkat singkatnya.

5. Daya lentur adalah efektivitas seseorang dalam penyelesaian diri untuk segala aktivitas dengan penguuran tubuh yang luas.

6. Kelincahan adalah kemampuan mengubah posisi diarea tertentu.

7. Koordinasi adalah kemampuan seseorang melakukan bermacammacam gerakan yang berbeda ke dalam pola gerakan tunggal secara efektif.

8. Keseimbangan adalah kemampuan tubuh untuk mempertahankan posisi, dalam bermacam-macam gerakan.

9. Ketepatan adalah kemampuan seseorang untuk mengendalikan gerakan bebas terhadap sasaran.

10. Reaksi adalah kemampuan seseorang untuk segera bertindak secepatnya dalam menggapai rangsangan yang ditimbulkan melalui indera, saraf atau feeling lainya. Seperti dalam mengantisipasi datangnya bola yang harus ditangkap dan lain-lain.

(Maliki, Hadi, \& Royana, 2016) Bila dilihat dari faktor internal, ada empat komponen yang mempengaruhi prestasi itu antara lain, kondisi fisik, teknik, taktik, dan mental. Kondisi fisik, teknik, taktik dan mental memiliki hubungan dan saling berkaitan. Dalam rangka untuk memperoleh prestasi, keempat komponen ini tidak dapat dipisahkan. Sebuah prestasi tidak dapat dicapai apabila salah satu dari keempat komponen ini tidak mewakili. Secara terperinci akan dijelaskan tentang komponen kondisi fisik yang digunakan dalam penelitian ini yaitu sebagai berikut:

\section{Daya Tahan (VO2Max)}

Pengertian ketahanan ditinjau dari kerja otot adalah kemampuan kerja otot atau sekelompok otot dalam jangka waktu tertentu, sedang pengertian ketahanan dari system energy adalah kemampuan kerja organ-organ tubuh dalam jangka waktu tertentu. Istilah ketahanan atau daya tahan dalam dunia olahraga dikenal sebagai kemampuan peralatan organ tubuh olahragawan untuk melawan kelelahan selama berlangsungnya aktivitas atau kerja. Latihan ketahanan dipengaruhi dan berdampak pada kualitas sistem kardiovaskuler, pernapasan dan system peredaran darah. Oleh karana itu faktor yang berpengaruh terhadap ketahanan adalah kemampuan maksimal dalam memenuhi komsumsi oksigen yang ditandai dengan VO2max.

Komponen biomotorik ketahanan pada umumnya digunakan sebagai salah satu tolok ukur untuk mengetahui tingkat kebugaran jasmani (physical fitness) olahragawan. Kebugaran jasmani adalah suatu keadaaan kemampuan peralatan tubuh yang dapat memelihara keseimbangan tersedianya energy sebelum, selama, dan sesudah aktivitas kerja berlangsung.

Menurut Sukadiyanto (2000:42) dayatahan adalah kemampuan jantung dan sistem pernafasan dalam mencukupi kebutuhan oksigen pada otot yang membakar glikogen agar menjadi sumber tenaga. Aktivitas permainan yang lama pada olahraga bulutangkis akan menguras stamina atlet, oleh karena itu daya tahan tubuh sangat diperlukan pada cabang olahraga bulutangkis.

\section{Daya Ledak Otot Tungkai}

Daya ledak otot tungkai merupakan komponen kondisi fisik yang sangat 
dibutuhkan dalam cabang olahraga bulutangkis. Para pemain dituntut untuk memiliki daya ledak otot tungkai yang sangat baik.

Daya ledak merupakan terjemahan dari kata explosive power atau power (bahasa Inggris). Power adalah kekuatan yang dilakukan dengan cepat (kekuatan $\mathrm{x}$ kecepatan), atau pengerahan gaya otot maksimum dengan kecepatan maksimum (Syahara, 2009:73). Jonath \& Krempel dalam Syafruddin (2011:73) mendefinisikan daya ledak sebagai kemampuan kombinasi kekuatan dengan kecepatan yang terealisasi dalam bentuk kemampuan otot untuk mengatasi beban dengan kecepatan kontraksi tinggi.

Menurut Harre dalam Nurhayati (2006: 20), daya ledak adalah kemampuan olahragawan untuk mengatasi tahanan dengan suatu kecepatan kontraksi tinggi. Dari beberapa pengertian daya ledak diatas dapat disimpulkan bahwa daya ledak otot tungkai adalah kemampuan otot tungkai dalam mengatasi tahanan ketika melakukan aktivitas secara cepat dan kuat untuk menghasilkan tenaga yang maksimal.

\section{Kekuatan Otot Lengan}

Kekuatan otot merupakan salah satu komponen fisik yang sangat penting peranannya dalam mendukung keberhasilan aktivitas manusia. Kekuatan merupakan salah satu fungsi penting yang harus dimiliki oleh seorang atlet, karena setiap gerakan dalam olahraga memerlukan kekuatan otot disamping unsur-unsur lain. Kekuatan otot juga memegang peranan penting dalam melindungi dari kemungkinan cidera. Menurut Irianto (2004: 4), kekuatan otot adalah kemampuan otot melawan beban dalam satu usaha. Kekuatan ototmerupakan unsur penting dalam tubuh manusia, karena kekuatan otot adalah komponen yang sangat penting untuk meningkatkan kondisi fisik secara keseluruhan. Dengan kekuatan otot yang lebih, tubuh manusia dapat melakukan kegiatannya dengan baik tanpa mengalami kelelahan yang berarti. Untuk mencapai prestasi yang maksimal, seseorang harus memiliki beberapa faktor yang yang penting yang dapat menunjang tercapinya prestasi maksimal. Otot merupakan salah satu penunjang bagi seseorang yang ingin mencapai prestasi maksimal. Otot akan berkontraksi lebih kuat apabila diberikan beban yang lebih berat (sampai pada batas maksimal). Apabila otot diregangkan kekuatannya berbeda-beda, hal ini tergantung pada besar atau panjang otot.

\section{Kecepatan}

Kecepatan merupakan komponen fisik yang mendasar, sehingga kecepatan merupakan faktor penentu didalam cabang olahraga seperti nomor-nomor lari jarak pendek, renang, olahraga beladiri dan olah raga permainan. Kecepatan yaitu kemampuan untuk melakukan gerakangerakan yang sejenis secara berturut-turut dalam waktu yang sesingkat-singkatnya atau kemampuan untuk menempuh suatu jarak yang sesingkat-singkatnya.

Secara fisiologis, kecepatan dapat diartikan sebagai kemampuan untuk melakukan gerakan-gerakan dalam satu satuan waktu tertentu yang ditentukan oleh fleksibilitas tubuh, proses sistem persarafan dan kemampuan otot. Sedangkan secara fisikalis kecepatan dapat diartikan sebagai jarak dibagi waktu, dan hasil dari pengaruh kekuatan terhadap tubuh yang bergerak, dimana kekuatan dapat mempercepat gerakan tubuh (Jonath \& Krempel dalam Syafruddin, 1999:43).

\section{Kelincahan}

Kelincahan merupakan unsur kondisi fisik yang sangat penting dalam cabang olahraga bulutangkis. Dalam melakukan teknik dengan baik dan taktik yang telah direncakan, kelincahan yang baik sangat dibutuhkan. Seorang pemain harus mampu membawa bola dengan cepat dan arah yang berbeda-beda untuk melindungi bola agar tidak direbut oleh pemain lawan. 
Kelincahan yang dilakukan oleh atlet bulutangkis saat berlatihmaupun bertanding tergantung pula oleh kemampuan mengkoordinasikansistem gerak tubuh dengan respon terhadap situasi dan kondisi yangdihadapi. Kelincahan ditentukan oleh faktor kecepatan bereaksi, kemampuan untuk menguasai situasi dan mampu mengendalikan gerakansecara tiba-tiba.

\section{Kelentukan}

Kelentukan menurut Setiawan (1991: 114) adalah kemampuan seseorang untuk dapat melakukan gerak dengan ruang gerak seluas-luasnya dalam persendiannya. Faktor utama yang menentukan kelentukan seseorang ialah bentuk sendi, elastisitas otot, dan ligamen. Menurut Ladi, Hendrajadja, dan Riyanto (2009: 11), kelentukan selalu dikaitkan dengan ruang gerak sendi dan elastisitas otot, tendon, dan ligamen. Dengan demikian, orang yang lentur adalah yang memiliki ruang gerak luas dalam sendisendinya dan yang memunyai otot yang elastis.

Kelenturan atau flexibility sering diartikan sebagai kemampuan seseorang untuk menggerakkan tubuh atau bagianbagian dalam satu ruang gerak yang seluas mungkin, tanpa mengalami cedera pada persendian dan otot sekitar persendian. Fleksibilitas memberikan kontribusi pada pekerjaan dan olahraga. Kurangnya fleksibilitas diimplikasikan dalam perkembangan cedera yang akut dan kronis dan masalah di bagian bawah punggung. Kita semua mendapat keuntungan dari latihan peregangan secara teratur, dan orang yang lebih tua memiliki kebutuhan khusus, karena jaringan yang berhubungan menjadi semakin tidak elastis.

\section{Manfaat Kondisi Fisik}

Dalam kegiatan olahraga, kondisi fisik seseorang akan sangat mempengaruhi bahkan menentukan gerak penampilannya. Menurut Harsono (1988: 153), dengan kondisi fisik yang baik akan berpengaruh terhadap fungsi dan sistem organisasi tubuh,di antaranya:

1. Akan ada peningkatan dalam kemampuan sistem sirkulasi dan kerja jantung.

2. Akan ada peningkatan dalam kekuatan, kelentukan, stamina, dan komponen kondisi fisik lainya.

3. Akan ada ekonomi gerak yang lebih baik pada waktu lainya.

4. Akan ada pemulihan yang lebih cepat dalam organisme tubuh kita apabila sewaktu-waktu respon diperlukan.

Peneilitian yang relevan dengan penelitian ini adalah penelitian yang diteliti oleh Osa Maliki dkk, dengan judul "Analisis Kondisi Fisik Pemain Sepakbola Klub Persepu UPGRIS Tahun 2016" Penelitian ini bertujuan untuk melihat tingkat kondisi fisik pemain klub Persepu UPGRIS yang meliputi daya tahan, daya ledak otot tungkai, kecepatan dan kelincahan. Metode penelitian ini merupakan penelitian deskriptif. Penelitian dilaksanakan di lapangan Sidodadi pada tanggal 31 Oktober 2016. Penelitian mengambil sampel sebanyak 40 orang pemain Persepu UPGRIS. Hasil penelitian menggambarkan bahwa rata-rata tingkat daya tahan (VO2max) pemain Persepu UPGRIS adalah 45,67 dengan kategori sedang. Rata-rata tingkat daya ledak otot tungkai pemain Persepu UPGRIS adalah $44 \mathrm{~cm}$ dengan kategori sedang. Rata-rata tingkat kecepatan pemain Persepu UPGRIS adalah 4,31 detik dengan kategori sedang. Rata-rata tingkat kelincahan pemain Persepu UPGRIS adalah 6,35 detik dengan kategori sedang.

\section{METODE PENELITIAN}

Peneilitian ini merupakan jenis penelitian deskriptif kuantitatif. Penelitian ini dilaksanakan di GOR UPGRIS dari bulan November 2017 sampai dengan bulan Januari 2018 dengan jadwal pelaksanakan mulai pukul 16.00 WIB sampai dengan selesai. Penelitian 
mengambil subjek penelitian atlet UKM Bulutangkis UPGRIS Putra berjumlah 24 mahasiswa. Variabel penelitian dalam penelitian ini terdiri dari daya tahan, daya ledak otot tungkai, kekuatan otot lengan, kecepatan, kelincahan, dan fleksibility. Teknik pengumpulan data yang digunakan teknik tes dan pengukuran. Instrumen Penelitian yang digunakan adalah:

1) Daya tahan diukur dengan multistage fitness test.

2) Daya ledak otot tungkai diukur dengan tes standing broad jump.

3) Kekuatan otot lengan diukur dengan handgrip dynamometer.
4) Kecepatan diukur dengan tes lari cepat 30 meter.

5) Kelincahan diukur dengan Illinois Agility Run Test.

6) Fleksibility diukur dengan Sit and Reach

\section{HASIL DAN PEMBAHASAN}

\section{Deskripsi Data}

Berdasarkan hasil tes dan pengukuran kecepatan atlet UKM Bulutangkis UPGRIS dengan lari sprint sejauh 60 meter diperoleh distribusi frekuensi yang dapat dilihat pada table berikut:

Tabel 1. Distribusi Frekuensi Kecepatan atlet UKM BulutangkisUPGRIS

\begin{tabular}{ccccc}
\hline \multirow{2}{*}{ No. } & Kelas Interval & \multicolumn{2}{c}{ Frekuensi } & Kategori \\
\cline { 3 - 4 } & & Absolut (Fa) & Relatif (\%) & \\
\hline 1. & s.d 7,79" & 0 & $0,00 \%$ & Sangat Baik \\
2. & $7,8 "-8,79 ”$ & 4 & $14,67 \%$ & Baik \\
3. & $8,8 "-9,99 "$ & 14 & $58,33 \%$ & Sedang \\
4. & $10,0 "-11,9 "$ & 6 & $25,00 \%$ & Kurang \\
5. & $11,9 "$ dst & 0 & $0,00 \%$ & Sangat Kurang \\
\hline & Jumlah & 24 & $100 \%$ & - \\
\hline
\end{tabular}

Berdasarkan tabel di atas, kecepatan atlet UKM bulutangkis UPGRIS dengan kategori sangat baik tidak ada (nol) orang, dengan nilai <7,79”. Kategori baik juga ada 4 (empat) orang dengan rentangan nilai 7,8 " $-8,79$ ". Kategori sedang ada 14 (empat belas) orang dengan rentangan nilai
8,8 - 9,99". Kategori kurang ada 6 (enam) orang dengan rentangan nilai 10,0" - 11,9'. Kategori sangat kurang tidak ada (nol) orang dengan nilai >11,9”. Penjelasan dalam bentuk diagram dapat dilihat dibawah ini :

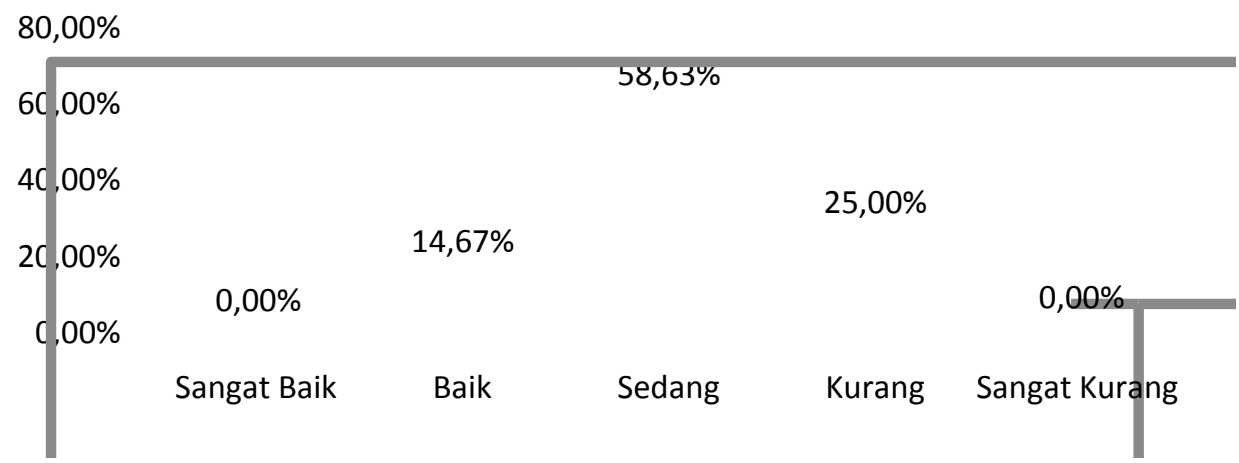

Gambar 1. Diagram Kecepatan Atlet UKM Bulutangkis UPGRIS 
JPOS (Journal Power Of Sports), 1 (1) 2018, (30-41)

Available at: http://e-journal.unipma.ac.id/index.php/JPOS

Utvi Hinda Zhannisa ${ }^{1}$, Ibnu Fatkhu Royana ${ }^{2}$, Bertika Kusuma Prastiwi ${ }^{3}$, Dani Slamet Pratama ${ }^{4}$

Berdasarkan hasil tes dan menggunakan agility run test, diperoleh pengukuran kelincahan atlet UKM Bulutangkis UPGRIS dengan distribusi frekuensi yang dapat dilihat pada tabel berikut:

Tabel 2. Distribusi Frekuensi Kelincahan atlet UKM BulutangkisUPGRIS

\begin{tabular}{ccccc}
\hline \multirow{2}{*}{ No. } & \multirow{2}{*}{ Kelas Interval } & \multicolumn{2}{c}{ Frekuensi } & \multirow{2}{*}{ Kategori } \\
\cline { 3 - 4 } & & Absolut $(\mathrm{Fa})$ & Relatif $(\%)$ & \\
\hline 1. & $<15,20$ & 0 & $0,00 \%$ & Sangat Baik \\
2. & $15,20-16,19$ & 15 & $62,50 \%$ & Baik \\
3. & $16,20-18,19$ & 9 & $37,50 \%$ & Sedang \\
4. & $18,20-19,30$ & 0 & $0,00 \%$ & Kurang \\
$\mathbf{5 .}$ & $>19,3$ & 0 & $0,00 \%$ & Sangat Kurang \\
\hline & Jumlah & 24 & $100 \%$ & - \\
\hline
\end{tabular}

Berdasarkan tabel di atas, kelincahan pemain atlet UKM Bulutangkis UPGRIS dengan kategori sangat baik tidak ada (nol) orang dengan nilai $<15,20$. Kategori baik ada 15 (lima belas) orang dengan rentangan nilai $15,20-16,19$. Kategori sedang ada 9 (sembilan) orang dengan rentangan nilai $16,20-18,19$. Kategori kurang tidak ada (nol) orang dengan rentangan nilai $18,20-19,30$. Kategori sangat kurang tidak ada (nol) orang dengan nilai $>19,30$. Penjelasan dalam bentuk diagram dapat dilihat dibawah ini:

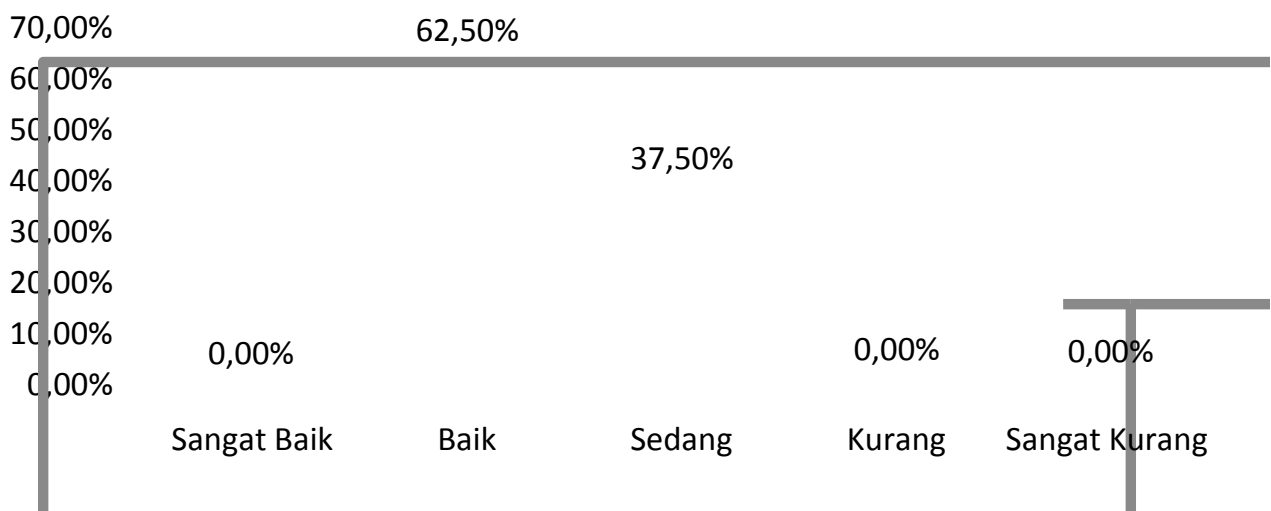

Gambar 2. Diagram Kelincahan Pemain UKM Bulutangkis UPGRIS Kekuatan Otot Lengan

Berdasarkan hasil tes dan pengukuran kekuatan otot lengan atlet UKM Bulutangkis UPGRIS dengan menggunakan leg dynamometer, diperoleh distribusi frekuensi yang dapat dilihat pada tabel berikut:

Tabel 3. Distribusi Frekuensi Kekuatan Otot TungkaiAtlet UKM Bulutangkis UPGRIS

\begin{tabular}{ccccc}
\hline \multirow{2}{*}{ No. } & Kelas Interval & \multicolumn{2}{c}{ Frekuensi } & Kategori \\
\cline { 3 - 4 } & & Absolut $(\mathrm{Fa})$ & Relatif $(\%)$ & \\
\hline 1. & $>55$ & 1 & $4.17 \%$ & Sangat Baik \\
2. & $46,50-54,50$ & 6 & $25,00 \%$ & Baik \\
3. & $36,50-46,00$ & 13 & $54,17 \%$ & Sedang \\
4. & $27,50-36,00$ & 4 & $16,67 \%$ & Kurang \\
5. & $<27$ & 0 & $0,00 \%$ & Sangat Kurang \\
\hline & Jumlah & 24 & $100 \%$ & -
\end{tabular}

Berdasarkan tabel di atas, kekuatan otot lengan atlet UKM Bulutangkis
UPGRIS dengan kategori sangat baik ada 1 (satu) orang dengan nilai $>55$. Kategori 
baik ada 6 (enam) orang dengan rentangan nilai 46,50 - 41,00. Kategori sedang ada 13 (tiga belas) orang dengan rentangan nilai 36,50 - 46,00. Kategori kurang ada 4 (empat) orang dengan rentangan nilai $27,50-24,00$
Kategori sangat kurang tidak ada (nol) orang dengan nilai $<29$. Penjelasan dalam bentuk diagram dapat dilihat dibawah ini :

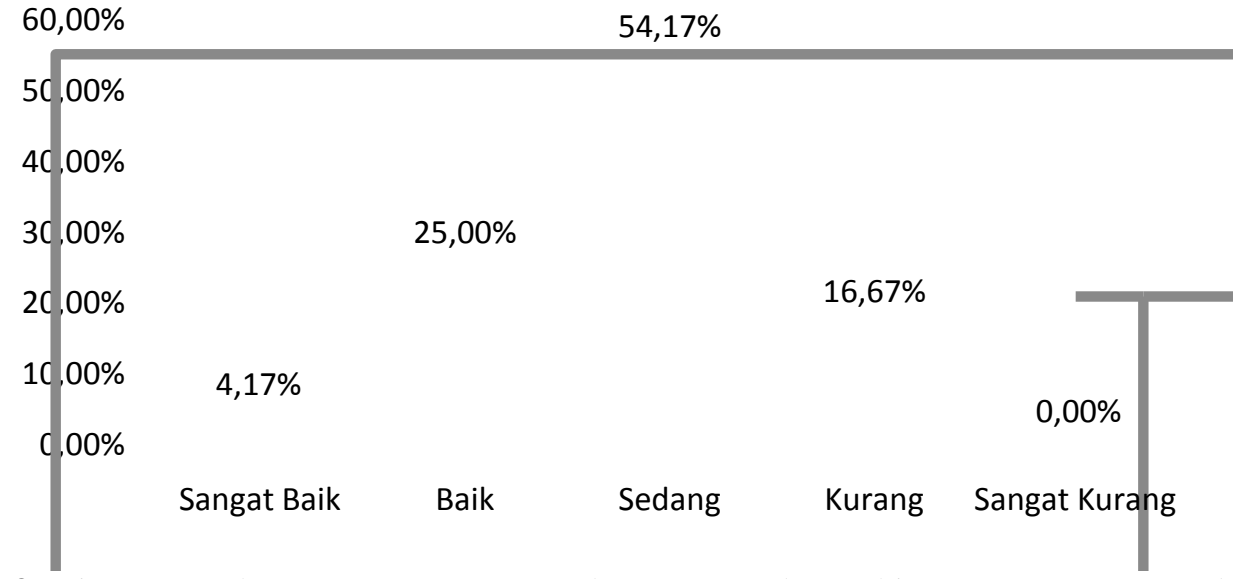

Gambar 3. Diagram Kekuatan Otot Lengan Atlet UKM Bulutangkis UPGRIS Daya Ledak Otot Tungkai

Berdasarkan hasil tes dan menggunakan tes standing board jump, pengukuran daya ledak otot tungkai atlet diperoleh distribusi frekuensi yang dapat UKM Bulutangkis UPGRIS dengan dilihat pada tabel berikut:

Tabel 4. Distribusi Frekuensi Daya Ledak Otot Tungkai Atlet UKM Bulutangkis UPGRIS

\begin{tabular}{ccccc}
\hline \multirow{2}{*}{ No. } & \multirow{2}{*}{ Kelas Interval } & \multicolumn{2}{c}{ Frekuensi } & \multirow{2}{*}{ Kategori } \\
\cline { 3 - 4 } & & Absolut $(\mathrm{Fa})$ & Relatif $(\%)$ & \\
\hline 1. & $>279$ & 0 & $0,00 \%$ & Sangat Baik \\
$\mathbf{2 .}$ & $254-279$ & 14 & $58,34 \%$ & Baik \\
3. & $220-253$ & 10 & $41,66 \%$ & Sedang \\
4. & $190-219$ & 0 & $0,00 \%$ & Kurang \\
$\mathbf{5 .}$ & $<190$ & 0 & $0,00 \%$ & Sangat Kurang \\
\hline & Jumlah & 24 & $100 \%$ & - \\
\hline
\end{tabular}

Berdasarkan tabel di atas, daya ledak otot tungkai atlet UKM Bulutangkis UPGRIS dengan kategori sangat baik tidak ada (nol) orang dengan nilai $>279$. Kategori baik ada 14 (empat belas) orang dengan rentangan nilai 254 - 279. Kategori sedang ada 10 (sepuluh) orang dengan rentangan nilai 220 - 253. Kategori kurang tidak ada (nol) orang dengan rentangan nilai 190 - 219. Kategori sangat kurang tidak ada (nol) orang dengan nilai < 190 . Penjelasan dalam bentuk diagram dapat dilihat dibawah ini : 


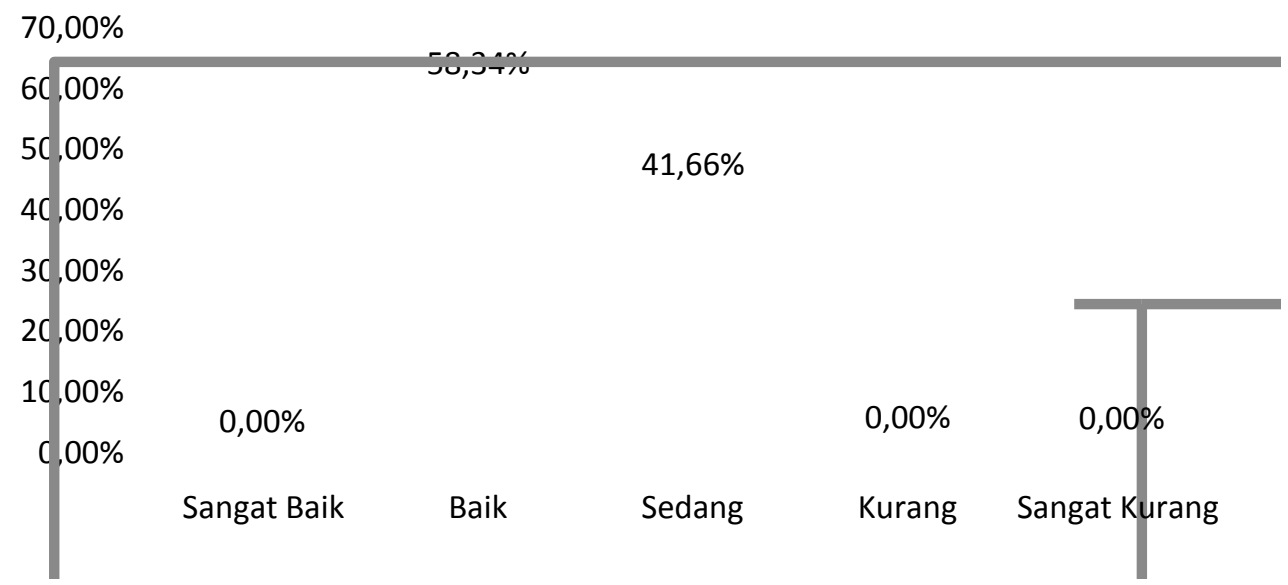

Gambar 4. Diagram Daya Ledak Otot TungkaiAtlet UKM Bulutangkis UPGRIS Daya Tahan (VO2max)

Berdasarkan hasil tes dan pengukuran daya tahan Atlet UKM Bulutangkis UPGRIS dengan

menggunakan multistage fitness test, diperoleh distribusi frekuensi yang dapat dilihat pada tabel berikut :

Tabel 5. Distribusi Frekuensi Daya Tahan (VO2max) Atlet UKM BulutangkisUPGRIS

\begin{tabular}{ccccc}
\hline \multirow{2}{*}{ No. } & \multirow{2}{*}{ Kelas Interval } & \multicolumn{2}{c}{ Frekuensi } & Kategori \\
\cline { 3 - 4 } & & Absolut $(\mathrm{Fa})$ & Relatif $(\%)$ & \\
\hline 1. & $>51,00$ & 0 & $0,00 \%$ & Sangat Baik \\
2. & $45,20-50,90$ & 5 & $20,84 \%$ & Baik \\
3. & $38,40-45,10$ & 11 & $45,83 \%$ & Sedang \\
4. & $35,00-38,30$ & 8 & $33,33 \%$ & Kurang \\
5. & $<35,00$ & 0 & $0,00 \%$ & Sangat Kurang \\
\hline & Jumlah & 24 & 100 & - \\
\hline
\end{tabular}

Berdasarkan tabel di atas, VO2max pemain Atlet UKM Bulutangkis UPGRIS dengan kategori sangat baik tidak ada (nol) orang dengan nilai $>51$. Kategori baik ada 5 (lima) orang dengan rentangan nilai 45,20 - 50,90. Kategori sedang ada 11 (sebelas) orang dengan rentangan nilai
$38,40-45,10$. Kategori kurang ada 8 (delapan) orang dengan rentangan nilai $35,00-38,30$. Kategori sangat kurang tidak ada (nol) orang dengan nilai $<35,00$. Penjelasan dalam bentuk diagram dapat dilihat dibawah ini:

\begin{tabular}{|c|c|c|c|c|c|}
\hline \multirow{2}{*}{$\begin{array}{l}50,00 \% \\
4 C, 00 \%\end{array}$} & \multicolumn{5}{|c|}{$45,83 \%$} \\
\hline & & & & $33,33 \%$ & \\
\hline $30,00 \%$ & & $20,84 \%$ & & & \\
\hline$c, 00 \%$ & & & & & \\
\hline$c, 00 \%$ & $0,00 \%$ & & & & $0,00 \%$ \\
\hline & Sangat Baik & Baik & Sedang & Kurang & $\begin{array}{l}\text { Sangat } \\
\text { Kurang }\end{array}$ \\
\hline
\end{tabular}

Gambar 5. Diagram Daya Tahan (VO2max)Atlet UKM Bulutangkis UPGRIS Kelentukan (Flexibility) 
Dari hasil analisis tabel di atas maka dapat Berdasarkan hasil tes dan pengukuran kelentukan Atlet UKM Bulutangkis UPGRIS dengan menggunakan alat sit and reach, diperoleh distribusi frekuensi yang dapat dilihat pada tabel berikut :

Tabel 6. Distribusi Frekuensi kelentukanAtlet UKM Bulutangkis UPGRIS

\begin{tabular}{ccccc}
\hline \multirow{2}{*}{ No. } & Kelas Interval & \multicolumn{2}{c}{ Frekuensi } & \multirow{2}{*}{ Kategori } \\
\cline { 3 - 4 } & & Absolut $(\mathrm{Fa})$ & Relatif $(\%)$ & \\
\hline $\mathbf{1 .}$ & $>28$ & 23 & $95,83 \%$ & Sangat Baik \\
$\mathbf{2 .}$ & $24-28$ & 1 & $4,17 \%$ & Baik \\
$\mathbf{3 .}$ & $20-23$ & 0 & $0,00 \%$ & Sedang \\
$\mathbf{4 .}$ & $17-19$ & 0 & $0,00 \%$ & Kurang \\
$\mathbf{5 .}$ & $<17$ & 0 & $0,00 \%$ & Sangat Kurang \\
\hline & Jumlah & 24 & 100 & - \\
\hline & & & & \\
\hline
\end{tabular}

Berdasarkan tabel di atas, kelentukanAtlet UKM Bulutangkis UPGRIS dengan kategori sangat baik berjumlah 23 (dua puluh tiga) orang dengan nilai $>28$. Kategori baik ada 1 (satu) orang dengan rentangan nilai 24 27.
Kategori sedang tidak ada (nol) orang dengan rentangan nilai $20-23$. Kategori kurang tidak ada (nol) orang dengan rentangan nilai 17 - 19. Kategori sangat kurang tidak ada (nol) orang dengan nilai $<17$. Penjelasan dalam bentuk diagram dapat dilihat dibawah ini :

\begin{tabular}{|c|c|c|c|c|c|}
\hline$c 0,00 \%$ & & & & & \\
\hline ع $0,00 \%$ & & & & & \\
\hline$\in 0,00 \%$ & & & & & \\
\hline$\angle 0,00 \%$ & & & & & \\
\hline $20,00 \%$ & & $4,17 \%$ & $0,00 \%$ & $0,00 \%$ & $0,00 \%$ \\
\hline $0,00 \%$ & & & & & \\
\hline & Sangat Baik & Baik & Sedang & Kurang & $\begin{array}{l}\text { Sangat } \\
\text { Kurang }\end{array}$ \\
\hline
\end{tabular}

Gambar 6. Diagram kelentukan (flexybility)Atlet UKM Bulutangkis UPGRIS

\section{KESIMPULAN}

Rata-rata tingkat kecepatan Atlet UKM Bulutangkis UPGRIS adalah 9,5 detik dengan kategori sedang. Rata-rata tingkat kelincahan Atlet UKM Bulutangkis UPGRIS adalah 16,35 detik dengan kategori baik. Rata-rata tingkat kekuatan otot lengan Atlet UKM Bulutangkis UPGRIS adalah 41,48 dengan kategori sedang. Rata-rata tingkat daya ledak otot tungkai Atlet UKM Bulutangkis UPGRIS adalah 251,79 cm dengan kategori sedang. Rata-rata tingkat daya tahan (VO2max) pemain tim futsal UPGRIS adalah 41,60 dengan kategori sedang.

\section{DAFTAR PUSTAKA}

Adnan, A. (2005). Tes dan Pengukuran Olahraga. Padang.

Arsil. (2008). Pembinaan Kondisi Fisik. Padang: FIK UNP.

Grace, T. (2008). Badminton: steps to success. 2nd edition. Chapingan: Human Kinetics. 
Harsono. (1988). Coaching dan AspekAspek Psikologis Dalam Olahraga. Jakarta: Depdikbud.

Irawadi, H. (2010). Kondisi Fisik dan Pengukurannya. Padang: FIK UNP.

Ismaryati. (2006). Tes dan Pengukuran Olahraga. Surakarta: 11 Maret University Press.

Kementrian Negara Pemuda dan Olahraga RI. (2005). Panduan Penetapan Parameter Tes Pada Pusat Pendidikan dan Pelatihan Pelajar dan Sekolah Khusus Olahragawan. Jakarta: Asisten Deputi Menpora.

Lubis, J. (2011). Mengenal Latihan Pliometrik. Jakarta: FIK UNJ.

Maliki, O., Hadi, H., \& Royana, I. F. (2016). Analisis Kondisi Fisik Pemain Sepak Bola Klub Persepu UPGRIS Tahun 2016. Jendela Olahraga, 2(2), 1-8.

Poerwadarminta. (1984). Kamus Umum Bahasa Indonesia. Jakarta: PN Balai Pustaka.

Rothig, P \& Grossing, S. (2004). Pengetahuan Training Olahraga (Alih Bahasa, Syafruddin). Padang: FIK UNP.

Sajoto, M. (1988). Pembinaan Kondisi fisik dalam olahraga. Jakarta: Departemen Pendidikan dan Kebudayaan Direktorat Jenderal Pendidikan Tinggi Proyek Pengembangan Lembaga pendidikan Tenaga Kepandidikan.

Subarjah, H. (2000). Bulutangkis. Jakarta: Departemen Pendidikan Dan Kebudayaan.

Sugiyono. (2009). Metode Penelitian Pendidikan. Bandung: Alfabeta.
Suharno, H. P. (1986) .Ilmu Kepelatihan Olahraga.Yogyakarta: Yayasan Sekolah Tinggi Olahraga.

Syafruddin. (1999). Dasar-Dasar Kepelatihan Olahraga. Padang: UNP.

Syahara, S. (2009). Pertumbuhan dan Perkembangan Fisik \& Motorik. Padang: FIK UNP. 